design and experimental verification of the conceptual grounds of the regional education policy requires a careful analysis of both the educational potential of the region and the study of the educational needs of its residents. In order to identify the educational needs of Zaporizhzhia region residents and the level of their satisfaction 400 respondents have been surveyed. The experiment was conducted in the form of a standardized interview using "face-to-face" method by means of a questionnaire which included 20 questions. It was designed according to the specific features of the respondents and was divided into conventional blocks making possible to identify the current state of the education services market in the region and assess its strengths and weaknesses; to analyze the structure of the education services market in the region; to determine educational needs and the needs of the region residents to sort out priorities concerning the opportunities for the education services market development. The analysis of the survey results has revealed the following factors influencing education development in the region: the availability and interrelation of different levels and forms of education; the need for cooperation and collaboration among all stakeholders of regional development, the resources sharing; the need for constant dialogue and use of feedback mechanisms in the development and implementation of regional programs and development strategies; the need to encourage the development of social partnership by establishing permanent links between various agencies and organizations of formal and informal education; the need to expand volunteer movement in informal education; the need to establish pilot projects as prospective resource centers for issues of education regional development management.

Keywords: lifelong education, adult education, learning city and region, educational needs, education services market.

Подано до редакиії 24.02.2017

UDC: 37.022

DOI: https://doi.org/10.24195/2414-4665-2017-2-18

Olena Korzh, PhD (Candidate of Pedagogical sciences), associate professor, Department of English for Specific Purposes, Vasyl' Stus Donetsk National University, 21, 600-richchia Str., Vinnitsia, Ukraine

\title{
BLOOM'S TAXONOMY AND ITS ROLE IN ACADEMIC WRITING AND READING SKILLS TRAINING AT ENGLISH CLASSES
}

Under modern changeable conditions of the information society, students do not need ready information, but they rather require the methods and best possible ways to obtain, comprehend and apply their knowledge. In the area of education, this leads to increased interest on the part of teachers both to the problem of formation and development of academic writing/reading skills at English classes, and to the problem of effective learning objectives setting. The issue of effective pedagogical goal setting for the development of students' academic writing/reading skills at English classes is currently one of the most significant in the field of higher education. At the same time, the purpose of the training determines what knowledge, skills and abilities students should possess after graduation, and educational tasks give the answer to the question of how to move towards the goal. The essence of the Bloom's taxonomy is considered in the article, both in the aspect of educational goal setting and in the development of students' academic writing/reading skills at English classes. Also, the advantages and disadvantages of applying the taxonomy in the educational process of higher education in general and in English language training in particular are given.

Keywords: educational process, thinking process, educational learning objectives, Bloom's taxonomy, higher education, levels of knowledge, cognitive area, learning activity, academic writing/reading skills, English classes, knowledge, comprehension, application, analysis, synthesis, evaluation.

\section{Introduction}

Modern educational process not only requires knowledge transmission from the teacher to the student, but also aims at educating motivated and determined students who will be focused on making a successful career in their future professional activities, as well as on the realization of the effective development of their life and professional path. Under contemporary conditions of infor- mation society, which are very unpredictable, students call for not only receiving ready information but also the methods of how to obtain it, comprehend and apply. Consequently highly developed academic writing/reading skills in the English language become of special importance. As a result, during English classes students acquire skills of gaining the knowledge necessary for their further self-development. Such processes in the field of education 
have led to an increased interest on the part of teachers to the formation and development of academic writing/reading skills in English among students, as well as to the effective educational goals setting in this area of professional education.

In the study of V. Mareyev it is pointed out that modern university education is a process built on the students' creative activities, and at the same time is a research process in its essence, which develops scientific (academic) thinking of students of all specialties; assumes the creative nature of the cooperative activity of a teacher and students [11]. S. Druzhilov emphasizes that the knowledge of a professional is defined not only by its amount, but also by its systematic character. However, he considers this to be insufficient for describing a worldclass professional and introduces the term of "eagerness", the essence of which is closely related to the systematic nature of knowledge, the ability of a person to immediately recall what is essential at the moment, and constant mobilization of the entire stock of knowledge [7].

The relevance of this issue is explained by the fact that effective educational goal setting for the development of academic writing/reading skills in English is currently one of the most significant in the field of higher education. At the same time, the objective of the training determines what kind of knowledge, skills and abilities in English a student should obtain by the graduation time, and the learning tasks at English classes should contribute to achieving the goal.

The paper aims to review the fundamentals of the Bloom's taxonomy, both in the aspect of educational goal setting and in the development of the students' academic writing/reading skills in English. Furthermore there is the task to identify the advantages and disadvantages of Bloom's taxonomy application in the educational process of higher education in general and in English language training specifically.

\section{Discussion}

For many years, experts in the field of education have sought to develop a perceptive and accessible theory that, on the one hand, would help teachers to effectively and systematically develop writing/reading skills in English in their students, and on the other hand, promote the correct setting of educational objectives in the course of English training. The most famous model describing and combining both the process of developing skills and setting effective goals of education is the Bloom's taxonomy, which includes six thinking skills, or educational learning objectives, from the most basic level to the most advanced one.

Taxonomy (from Ancient Greek 'taxis' - arrangement, order and 'nomos' - the law or science) is the theory of classification and systematization of organized areas of reality, usually having a hierarchical structure (organic world, objects of geography, geology, linguistics, ethnography, etc.) [7]. The notion of "taxonomy" was introduced for the first time in 1813 by the Swiss botanist Augustin de Candolle who worked at the classification system of plants. In the area of education, taxonomy is the structure of a comprehensible system of educational objectives, within which their categories and consecutive levels are singled out $[8,145]$.

Some domestic scientists dealt with the correct setting of educational teaching objectives and developing the skills of writing/reading skills in English. Thus, $\mathrm{S}$. Arkhanhelskyi believes that the educational process in higher education is not only a scheme of communication and accumulation of knowledge, or skills and abilities training, but it is also a complex system of organizing, managing and developing cognitive activity of students, this is the process of comprehensive development of a highly qualified specialist. Consequently, in modern higher education knowledge, abilities and skills are no longer the subject of educational activity, but they have become the means of professional activity [5]. In the study of S. Arkhanhelskyi, a characteristic of four different levels of knowledge acquisition is presented, that is, the perception and transformation of educational information [5]. In the interpretation of V. Bespalko, I. Lerner, and M. Skatkin, the levels of acquisition of scientific information are presented in the following sequence:

- identification, i.e. imitation;

- reproduction, i.e. memorization, the ability to apply the acquired information in practical activities;

- transformation that allows to orientate in a new situation and develop a modified program of actions based on the knowledge gained [11]. The discovered conditions and levels of mastering the educational material determine the concept of the contents of learning in higher education as a pedagogically substantiated, logically considered and reflected in the educational documentation scientific information about the material to be studied.

There is also a classification of educational objectives proposed by V. Teslenko. The author outlines the following steps of knowledge mastering:

1. Informational level, requiring a student to identify familiar information.

2. Reproductive level, the main operations of which are the reproduction of information and algorithmic transformations.

3. Basic level, requiring a student to understand the essential aspects of educational information, and know the general principles of algorithmic search.

4. Advanced level, requiring a student to convert algorithms into conditions, which differ from standard ones, and be able to conduct heuristic search.

5. Creative level, meaning that a student possesses skills of an independent critical evaluation of educational information, the ability to solve non-standard tasks, and knowledge of the elements of research [9].

B. Bloom believed that there are skills of low-level thinking (knowledge and understanding) and high-level thinking (application, analysis, evaluation, synthesis). Most of the thinking processes peculiar for learning activity correspond to the levels of knowledge and understanding that are the simplest in mental activity, and they are 
also the basis for high-level thinking skills. With each successive level, the cognitive skills become more sophisticated [2].

B. Bloom is not only the author of the first detailed scheme of levels of thinking, but also he invented a system which describes the objectives of the cognitive area and the criteria for evaluating the level of mental activity in the learning process. Within the frames of the educational technology B. Bloom created the first taxonomy of educational objectives in 1956. At that time B. Bloom and D. Krathwall divided the goals of education into three areas: cognitive (required mastering the contents of the subject), psychomotor (development of motor, neuromuscular activity) and affective (emotional-value area, attitude to the studied material).

The first taxonomy covers the cognitive domain and includes six categories of goals with the following division:

- knowledge (specific material, terminology, facts, definitions, criteria, etc.);

- comprehension (explanation, interpretation, extrapolation);

- application (apply abstractions, general principles, or methods to specific concrete situations);

- analysis (separation of a complex idea into its constituent parts and understanding of organization and relationship between the parts. It includes realizing the distinction between hypothesis and fact as well as between relevant and extraneous variables);

- synthesis (creative, mental construction of ideas and concepts from multiple sources to form complex ideas into a new, integrated, and meaningful pattern subject to given constraints);

- evaluation (to make a judgment of ideas or methods using external evidence or self-selected criteria substantiated by observations or informed rationalizations) [1].

The main advantage of Bloom's taxonomy is that thinking is presented there in a structured and accessible form suitable for practitioners. Despite the fact it was developed more than 40 years ago, it still remains one of the most popular systematization of educational objectives among scientists as well as practical teachers. Moreover, it can be practically applied in the process of higher education and particularly in the area of training academic writing/reading skills in English. It is the most comprehensive system and covers various areas of students' learning activities: cognitive (cognitive domain), affective (affective domain), psycho-motor (psycho-motor domain). Bloom's taxonomy is based on the following four principles:

- practical orientation: taxonomy should reflect the theory of goal-setting, and also be an effective instrument for teachers-practitioners;

- psychological: taxonomy should be based on modern achievements of psychological science;

- logical: taxonomy should be logically completed and possess internal harmony;
- objectivity: the hierarchy of goals does not mean the hierarchy of their importance.

The cognitive field of taxonomy includes six levels given above; each of them contains the system of its own goals. Thus, the level of knowledge involves the development of learning goals aimed at memorizing, recognizing and reproducing the basic elements of educational information in the area of English language. The goals of this level involve the development of knowledge in the following three categories:

- specific knowledge (for example, dates, facts, numbers, terms, names);

- procedural knowledge (for example, criteria, directions, categories, classes);

- abstract knowledge (for example, principles, axioms, theorems, generalizations, theories, structures).

The level of comprehension includes educational objectives of three categories:

- translation (for example, the ability to translate a task from English into Ukrainian);

- interpretation (for example, the ability to explain the obtained solution in the certain language);

- extrapolation (for example, the ability to use the acquired knowledge in a similar situation).

The level of application implies the development of practical skills of students to use particular knowledge in practical situations. It can also be represented by the following corresponding sublevels:

- application of concepts;

- application of methods, algorithms;

- application of theories.

The level of analysis contains educational objectives in the following categories:

- analysis of elements (separation, division of the whole into parts);

- analysis of relations (establishing links between elements);

- analysis of principles (systematization of elements).

The level of synthesis, which includes the learning objectives for developing skills to compile the whole from individual parts, consists of the following categories:

- synthesis of ideas (for example, the search for an idea of solving a problem);

- synthesis of the procedure (for example, the development of a plan, the sequence of operations to solve a problem);

- synthesis of structure (for example, the construction of a function, set, group).

The evaluation level, which involves the availability of diagnostic skills and the development of critical thinking, includes the following categories:

- evaluation based on internal knowledge and beliefs (reasoning, logic, constructiveness);

- evaluation based on external criteria (standards, rules, norms).

This analysis increases the awareness of the teacher's actions towards the student, since it allows to organize the activity at different levels of mental operations and 
arrange learning process to develop academic writing/reading skills in English. In addition, conscious and consistent development of cognitive skills increases the efficiency of learning activity in the field of studying English, and generalization of the results and the discussion of errors committed, taking into account the analysis of mental operations, are necessary so that students could possibly correct their understanding of their actions, which is also a learning experience.

Along with the benefits, Bloom's taxonomy has certain disadvantages. Thus, in taxonomy that classifies learning objectives in the cognitive domain, the cognitive structure itself is not clearly visible at the level of perception, memory, thinking, intuition, and other mental processes. There is also some repetition of categories at various levels of learning objectives; for example, the category of extrapolation at the level of comprehension is largely corresponding to the category of application of concepts. The "application-analysis-synthesis" link has not been sufficiently developed from the point of view of their hierarchy. In this regard, G. Madaus and his colleagues proposed their own taxonomy modification, which unlike the strictly consistent Bloom's taxonomy is more flexible and bendy classification that eliminates the contradiction in the "application-analysis-synthesis" link [3, 253-262].

Bloom's taxonomy has also been repeatedly criticized by domestic scientists, because it confused particular learning outcomes (knowledge, comprehension, application) with mental operations, which are required to achieve those outcomes (analysis, synthesis, evaluation). The basis of the domestic developments is a tiered systemic approach which describes the achievements of students in the subject studied (English), and makes it possible to group the results of training depending on the levels of educational activities.

According to A. Mayorov, nowadays there are no domestic scientific developments in the field of education which allow not only to evaluate the level of development of students' academic writing/reading skills in English, but also to effectively set educational objectives in this area. This aspect presents the following difficulties:

- suggested levels of comprehension of educational material should be indisputably taken for granted by the pedagogical community;

- they should achieve a mutual correspondence between the difficulty of a particular task and the level of comprehension of the dominant content element presented;

- it is difficult to acquire a complete correlation between all possible knowledge and methods of activity [10].

\section{REFERENCES}

1. Anderson, L., Krathwohl, D. (2001). A taxonomy for learning, teaching, and assessing. New York: Longman,
The research of a more accurate and sufficient basic concept of the taxonomy of thinking skills was subsequently carried out by several cognitive psychologists. In the development of his taxonomy of educational learning goals, R. Marzano reveals one weak point of Bloom's taxonomy. The very structure of the taxonomy, built on the progress from the simplest level of knowledge to the advanced level of evaluation, is not supported by researches. Hierarchical taxonomy implies that each skill of a higher level is based on previous skills; that is, comprehension requires knowledge, application requires comprehension and knowledge and so on. This position of Bloom's taxonomy, according to R. Marzano, is simply incorrect [4].

\section{Conclusions}

Thus, in the framework of the modern information society, Bloom's taxonomy evokes a new surge of research interest, since it can be regarded as a fundamental concept in the modern theory of education and especially in the field of training and development of academic writing/reading skills in English. It provides a possibility to simultaneously take into consideration the levels of difficulty in English learning process and makes it possible not only to shift from one level of complexity to another, but also to monitor the progress of students in this area of knowledge, subject to continuity in types and organization of assignments. The purpose of Bloom's taxonomy in English language teaching is to motivate educators to focus on all three domains (cognitive, affective and psychomotor), thus offering the most comprehensive form of education. As a consequence it plays a special role in the educational process of the higher educational institutions, for the reason that taxonomy:

- contributes to the development of students' academic writing/reading skills in English;

- allows to correctly set the educational learning objectives in the area of English studying;

- allows to correctly present the tasks and prepare assignments for students according to six levels of cognitive domain;

- provides an opportunity to select evaluation tools adequate to the objectives;

- allows to conduct reflection of the learning outcomes correctly, i.e. to identify the difficulties the students have experienced in studying English.

Bloom's Taxonomy requires further studying in the aspect of its adaptation to domestic realities and development of teaching methods for its current practical application in the educational process of higher and secondary schools at English language classes.

2. Bloom, B. (1994). Taxonomy of educational objectives: The classification of educational goals: handbook I, cognitive domain. New York: Longman. 
3. Madaus, G. F. (1973). A Causal Model Analysis of Bloom's Taxonomy. American Educational Research Journal, 10, 253-262.

4. Marzano, R. (2000). Designing a new taxonomy of educational objectives. Thousand Oaks, CA: Corwin Press.

5. Arkhangelskiy, S. I. (1980). Uchebnyy protsess $v$ vysshey shkole, yego zakonomernyie osnovy $i$ metody [Educational process in the higher school, its logical foundations and methods]. Moscow [in Russian].

6. Druzhilov, S. A. (2010). Osnovy psychologii professionalnoy deyanelnosti ingererov-electricov [Fundamentals of the psychology of professional activity of electrical engineers]. Moscow: "Academiya estestvoznaniya" [in Russian].

7. Gilyarov, M. S., Babayev, A. A., Vinberg, G. G., Zavarzin, G. A. (1986). Biologicheskiy entsiklopedi-

\section{ЛИТЕРАТУРА}

1. Anderson L., Krathwohl D. A taxonomy for learning, teaching, and assessing / L. Anderson, D. Krathwohl. - New York: Longman, 2001.

2. Bloom B. Taxonomy of educational objectives: the classification of educational goals: handbook I, cognitive domain / D. Bloom. - New York: Longman, 1994.

3. Madaus G. F. A Causal Model Analysis of Bloom's Taxonomy / G. F. Madaus, E. N. Woods, R. L. Nuttal // American Educational Research Journal. 1973. - 10. - C. 253-262.

4. Marzano R. Designing a new taxonomy of educational objectives / R. Marzano. - Thousand Oaks, CA: Corwin Press, 2000.

5. Архангельский С. И. Учебный процесс в высшей школе, его закономерные основы и методы / С. И. Архангельский. - М. - 1980. -368 с.

6. Гиляров М. С. Биологический энциклопедический словарь / М. С. Гиляров, А. А. Бабаев, Г. Г. Винберг, Г. А. Заварзин. - М.: Сов. Энциклопедия, 1986. $864 \mathrm{c}$. cheskiy slovar [Biological encyclopedic dictionary]. Moscow: Sov. Encyclopedia [in Russian].

8. Kodzhaspirova, G. M, Kodzhaspirov, A. Yu. (2000). Pedagogicheskiy slovar [Pedagogical dictionary]. Moscow: "Academiya" [in Russian].

9. Teslenko, V. I. (2010). Kontseptualnoye osmysleniye otsenki i izmereniya rezultatov obucheniya [Conceptual comprehension of evaluation and measurement of learning outcomes]. Psychologiya obucheniya - Psychology of learning, 10, 124-142 [in Russian].

10. Mayorov, A. N. (2010). Osnovy pedagogicheskih izmereniy [The fundamentals of pedagogical measurements]. Moscow: Logos [in Russian].

11. Mareyev, V. I. (1999). Issledovatelskaya deyatelnost $v$ pedagogicheskom vuze: teoriya i praktika [Research activities in pedagogical university: theory and practice]. Rostov-na-Donu [in Russian].

7. Дружилов С. А. Основы психологии профессиональной деятельности инженеровэлектриков / С. А. Дружилов . - М. : Издательство «Академия Естествознания», 2010. - 119 с.

8. Коджаспирова Г. М., Коджаспиров А. Ю. Педагогический словарь: для студ. высш. и сред. пед. учеб. заведений / Г. М. Коджаспирова, А. Ю. Коджаспиров . - М.: Издательский центр «Академия», 2000. - $176 \mathrm{c}$

9. Тесленко В. И. Концептуальное осмысление оценки и измерения результатов обучения / В. И. Тесленко // Психология обучения. - 2010. №10. - С. 124-142.

10. Майоров А. Н. Основы педагогических измерений: учебное пособие / А. Н. Майоров. - М.: Логос, 2010

11. Мареев В. И. Исследовательская деятельность в педагогическом вузе: Теория и практика / В. И. Мареев. - Ростов-на-Дону, 1999. - 202 с.

Олена Юріївна Коржс, кандидат педагогічних наук, доцент кафедри іноземних мов професійного спрямування, Донеиький національний університет імені Василя Стуса, вуличя 600-річчя, 21, м. Вінниця, Украӥна

\section{ТАКСОНОМІЯ БЛУМА ТА ЇЇ РОЛЬ У ФОРМУВАННІ НАВИЧОК АКАДЕМІЧНОГО ПИСЬМА ТА ЧИТАННЯ НА ЗАНЯТТЯХ 3 АНГЛЙСЬКОӤ МОВИ}

В сучасних мінливих умовах інформаційного суспільства студенти потребують не стільки готової інформації, скільки методів іï отримання, осмислення і застосування. У сфері освіти це веде до зростання інтересу з боку педагогів як до проблеми формування і розвитку у студентів навичок академічного письма/читання на заняттях 3 англійської мови, так і до проблеми ефективної постановки педагогічних цілей. Актуальність теми полягає в тому, що проблема ефективного педагогічного цілепокладання для розвитку навичок академічного письма/читання на заняттях з англійської мови наразі є однією з головних у сфері вищої освіти. При цьому мета навчання визначає, якими знаннями, уміннями і навичками повинен володіти той, кого навчають, після закінчення навчання, а завдання навчання відповідають на питання, як рухатися до мети. Метою статті $є$ аналіз сутності таксономії Блума, як в аспекті педагогічного цілепокладання, так і в аспекті розвитку навичок академічного письма/читання на заняттях з англійської мови. Також ставиться завдання виявити переваги та недоліки ії застосування як в освітньому 
процесі вищої школи, так і в процесі викладання англійської мови. Протягом багатьох років фахівці в галузі освіти прагнули розробити наочну і доступну теорію, яка, з одного боку, допомогла б педагогам в ефективному і систематичному розвиткові у студентів навичок письма/читання на заняттях з англійської мови, а з іншого, - сприяла б правильній постановці педагогічних цілей у навчанні англійській мові. Найвідомішою моделлю, яка описує як процес набуття знань, так і цілі освіти, є таксономія Блума (Bloom’s Тахоnomy), що включає в себе шість навичок мислення, або педагогічних цілей навчання, представлених від базового до найвищого рівня. В умовах сучасного інформаційного суспільства таксономія Блума викликає новий сплеск дослідницького інтересу, адже ії можна розглядати в якості основної концепції в сучасній теорії навчання i, зокрема, в галузі розвитку навичок академічного письма/читання на заняттях з англійської мови. Вона дозволяє одночасно враховувати рівень складності у навчанні англійської мови і дає можливість не тільки переходити від одного рівня складності до іншого, а й стежити за прогресом учнів саме у цій галузі знання за умови наступності в типах і організації завдань. Мета таксономії Блума у викладанні англійської мови - мотивувати педагогів фокусуватися на всіх трьох сферах (когнітивній, афективній і психомоторній), пропонуючи, таким чином, найбільш повну форму навчання.

Ключові слова: освітній процес, процес мислення, педагогічне цілепокладання, таксономія Блума, вища освіта, рівні засвоєння знань, когнітивна область, навчальна діяльність, навички академічного письма/читання, заняття з англійської мови, знання, розуміння, застосування, аналіз, синтез, оцінювання.

Submitted on February, 24, 2017

Reviewed by Doctor of Pedagogy, prof. T. Kharchenko

UDC: $378.147: 811.111$

DOI: https://doi.org/10.24195/2414-4665-2017-2-19

Svitlana Pampura,

PhD (Candidate of Linguistic Sciences), Department of Foreign Languages, Donbas State Pedagogical University, 19, G. Batiuka Str., Sloviansk, Ukraine

\section{THE CASE STUDY METHOD AS A MEANS OF INCREASING MOTIVATION OF STUDENTS MAJORING IN PSYCHOLOGY FOR LEARNING ENGLISH}

The article deals with the issue of teaching English for students majoring in non-linguistic specialities. The review of theoretical resources has shown that the modern level of intercultural communication demands transformation in the system of vocational training for students of non-linguistic specialities and introduction of multidimensional teaching of foreign languages for special purposes. It has been stated that motivation for learning English is an essential factor in the process of successful development of professional competences. The use of the case study method in teaching English has proved its effectiveness for increasing motivation and creating good opportunities for implementation of interdisciplinary links.

Key words: foreign language teaching, innovative technologies, professional competence, motivation of students majoring in non-linguistic specialities, case study method, interdisciplinary links.

\section{Introduction}

The current state of the international relations of Ukraine requires considerable changes of the educational system. The issue of socialization of young people in interethnic and intercultural space acquires special significance and causes the necessity of developing new approaches to foreign language teaching. Knowledge of a foreign language is considered as one of the means to expand the professional competence and skills of students. University graduates should master a foreign language at the level sufficient for their professional and personal communication. Nowadays a good level of English enlarges greatly applicants' chances to find an interesting and well-paid job, to get a promotion, to enjoy close relations with business partners. Therefore, efficient teaching and high quality of the knowledge acquired are in urgent need. Today teachers face the task not only to provide students with linguistic knowledge but to form special competence necessary for their future work.

Though the issue of English teaching has been studied by many scholars: D. A. Wilkins, H. G. Widdowson, N. D. Glazkova,T. Yu. Zagriazkina,G. A. Kytaigorodskai a and others - it should be recognized that the level of fluency in foreign languages of university graduates does not always meet modern requirements. Needless to say that the success achieved depends considerably on the degree of the students' motivation. 